\title{
IMPLEMENTASI PENDIDIKAN KARAKTER BERBASIS BUDAYA SEKOLAH MELALUI PENERAPAN SISTEM BOARDING SCHOOL DI SMP IT GENERASI MUSLIM CENDEKIA LOMBOK TENGAH
}

\author{
Shodiqin \\ Institut Agama Islam Hamzanwadi NW Lombok Timur \\ Email :shodiqin2394@gmail.com
}

\begin{abstract}
This study aims to reveal the implementation of school culture-based character education through the application of the boarding school system at the Islamic Junior High School of Islamic Cendekia Generation in Central Lombok, with the focus of research, namely: (1) character values developed, (2) strategies used, ( 3) implications for student character. This research uses a qualitative approach with the type of case study research. The results of the study indicate that: 1) the character values developed at the Islamic Junior High School of the Generation of Muslim Cendekia through the application of the boarding school system include values: religious, disciplined, respectful, polite, social care and environmental care. 2) the strategy for implementing character education based on school culture through the application of the boarding school system at the Islamic Junior High School of the Muslim Cendekia Generation in Central Lombok includes: internalization of positive values by all school members, exemplary, habituation and enforcement of discipline. 3) the implications of character education based on school culture through the application of the boarding school system at the Islamic SMP Terpadu Generasi Muslim Cendekia Central Lombok on the character of students include: implications for spiritual attitudes, implications for discipline, implications for social attitudes and implications for morals and behavior.
\end{abstract}

Keywords: Implementation of Character Education; Boarding school

\begin{abstract}
Abstrak. Penelitian ini bertujuan untuk mengungkapkan implementasi pendidikan karakter berbasis budaya sekolah melalui penerapan sistem boarding school di SMP Islam Terpadu Generasi Muslim Cendekia Lombok Tengah, dengan fokus penelitian, yaitu : (1) nilai-nilai karakter yang dikembangkan, (2) strategi yang digunakan, (3) implikasi terhadap karakter siswa. Penelitian ini menggunakan pendekatan kualitatif dengan jenis penelitian studi kasus. Hasil penelitian menunjukkan bahwa : 1) nilainilai karakter yang dikembangkan di SMP Islam Terpadu Generasi Muslim Cendekia melalui penerapan sistem boarding school meliputi nilai: religius, disiplin, hormat, santun, peduli sosial dan peduli lingkungan. 2) strategi implementasi pendidikan karakter berbasis budaya sekolah melalui penerapan sistem boarding school di SMP Islam Terpadu Generasi Muslim Cendekia Lombok Tengah meliputi : internalisasi nilai-nilai positif oleh semua warga sekolah, keteladanan, pembiasaan dan penegakan disiplin. 3) implikasi pendidikan karakter berbasis budaya sekolah melalui penerapan sistem boarding school di SMP Islam Terpadu Generasi Muslim Cendekia Lombok Tengah terhadap karakter siswa meliputi : implikasi terhadap sikap spiritual, implikasi terhadap kedisiplinan, implikasi terhadap sikap sosial dan implikasi terhadap akhlak dan perilaku.
\end{abstract}

Kata Kunci : Implementasi Pendidikan Karakter; Boarding school. 


\section{PENDAHULUAN}

Permasalahan karakter masih merupakan isu besar yang dihadapai bangsa Indonesia saat ini. Berbagai konsep dan desain tentang pendidikan karakter dimunculkan sebagai upaya dalam memperbaiki serta memajukan kualitas karakter bangsa. Karakter sebagai fondasi utama dalam pendidikan nasional mesti ditempatkan kembali pada posisi prioritas yang mampu berdampingan dengan intelektualitas (Hasan dan Firdaos 2017).

Perilaku masyarakat khususnya peserta didik yang masih jauh dari nilai falsafah pancasila yang religious, humanis, nasionalis, demokratis, dan integritas menjadi faktor pendorong terhadap perbaikan tersebut (Khamalah 2017)menjadi salah satu faktor penting yang pendorong terhadap perbaikan pendidikan karakter. Pada sisi yang lain pendidikan karakter dihadapkan pada revolusi industri 4.0 yang ditandai dengan era digitalisasi. Kondisi ini tentu memberikan pengaruh pada pola perilaku peserta didik. Perkembangan teknologi informasi yang cepat ini harus diimbangi dengan kesiapan mental dan kompetensi mengingat persaingan dimasa depan yang semakin kompetitif.

Pengembangan karakter anak menghadapi revolusi industri 4.0 perlu mendapatkan perhatian serius dari berbagai pihak. Lebih lanjut ia mengatakan bahwa kesempatan ini harus dimanfaatkan untuk melatih anak supaya bisa berfikir positif, mengajarkan anak untuk bisa memilih dan memilah informasi(Setio A. Dewo 2018). Apa yang telah diungkapkan oleh Setio A. Dewo tersebut berangkat dari suatu kesadaran bahwa teknologi informasi yang berkembang secara cepat tentunya membawa dampak terhadap sikap dan perilaku. Salah satunya yaitu munculnya sikap indvidualistik pada diri seseorang sebagai akibat dari kecanduan smartphone ataupun gadget.

Seperti diungkapkan pula oleh Umi Dayati bahwa kemajuan teknologi informasi hendaknya disikapi dengan bijaksana, apabila tidak maka justru akan membawa dampak negatif. Lebih lanjut ia menuturkan fenomena yang terjadi dimana orang 
duduk bersebelahan tetapi tidak menjalin komunikasi karena sibuk dengan handphone dan gadget masing-masing. Kondisi ini menurutnya sangat menghawatirkan karena berdampak pada terkikisnya budaya sosialisasi dan tergantikan dengan egoisme yang tinggi (Umi Dayati 2018).

Kecanggihan teknologi informasi selain memunculkan sikap yang individualistik juga pada kondisi yang lain kurang mampu menumbuhkan akhlak mulia(Mulkhan 2016). Perkembangan teknologi informasi yang kian pesat justru membawa seseorang semakin terlena, memunculkan sikap enggan bertanggung jawab terjadinya dekadensi moral serta meningkatnya berbagai aksi kejahatan(Syamsuar dan Reflianto 2019) Penyebaran informasi melalui televisi, media social seperti Facebook, WhatsApp, Instagram tentang kasus-kasus kriminal, narkoba, asusila dan lainnya yang pada dasarnya bertujuan sebagai langkah antisipasi dan pengetahuan justru dijadikan sebagai inspirasi untuk melakukan berbagai penyimpangan dan tindakan kejahatan lainnya. Sehingga patutlah dikatakan bahwa kemerosotan akhlak atau dekadensi moral merupakan konsekuensi logis yang disebabkan oleh kemajuan teknologi dan informasi (Haidar Putra Daulay, 2012).

Pendidikan karakter dalam hal ini harus mampu merespon serta memberikan solusi dari permasalahan tersebut. Namun fakta dilapangan menunjukkan bahwa pendidikan karakter yang diberikan di sekolah-sekolah masih memiliki sejumlah kekurangan-kekurangan. Beberapa diantaranya adalah pola pembelajaran yang masih terfokus pada pembelajaran didalam kelas atau masih terfokus hanya pada penyampaian teori-teori di dalam kelas. Ki Hajar Dewantara mengungkapkan bahwa selama sekolah tetap fokus secara eksklusif pada pengembangan kecerdasan dan pemberian pengetahuan, maka itu akan tetap" opersonal "(kehilangan jiwa) sehingga akan memberikan pengaruh yang sedikit terhadap pembentukan karakter dan perkembangan perasaan sosial(Purnama, Marzuki, dan Utami 2018)

Selain itu juga, seringkali pembelajaran didalam kelas masih bersifat pasif dan kaku sehingga mengakibatkan kejenuhan kebosanan bahkan tidak jarang membuat siswa tertidur(Munjiatun 2018). Pendidikan akhlak atau moral masih terbatas hanya pada teori dan hafalan semata, dengan kata lain kuat dalam teori namun lemah dalam prakteknya. Zamroni mengungkapkan bahwa pendidikan yang dibutuhkan dalam menghadapi perubahan dan tantangan zaman adalah pendidikan yang berwawasan global, pendidikan yang memiliki nilai fleksibel terhadap perubahan dan 
kemajuan zaman akan tetapi tidak menghilangkan nilai moral keagamaan dan tetap eksis didalamnya(Iskarim 2017)

Pendidikan karakter berbasis budaya sekolah melalui penerapan sistem boarding school merupakan langkah yang tepat dalam mengoptimalisasikan proses transfer of knowledge dan transfer of value (Nurul Zuriah 2008). Pendidikan Karakter ini tentu tidak cukup apabila hanya bertumpu pada pembelajaran didalam kelas terlebih dalam proses transfer of value, oleh karena itu dibutuhkan suatu budaya sekolah yang didalamnya terjadi pembelajaran, habituasi, pembiasaan karakter secara terus menerus.

Melalui budaya sekolah yang didukung dengan penerapan sistem boarding school tesebut proses pembelajaran, habituasi, keteladanan, pembiasaan akan berjalan lebih intensif dan konsisten. Melalui pelibatan seluruh warga sekolah pula akan menjadikan pembentukan karakter melalui proses keteladanan, penularan serta intervensi diantara semua warga sekolah tidak hanya antara pendidik dan peserta didik lebih efektif. Pendidikan karakter melalui budaya sekolah yang dilakukan secara konsisten ini diharapkan mampu membentuk kepribadian peserta didik dan menjadi fonadasi dalam membangun manusia Indoneisa yang bertakwa dan mampu bersaing (Murniyetti, Engkizar, dan Anwar 2016)

SMP IT GMC (Generasi Muslim Cendekia) Lombok Tengah merupakan SMP swasta yang memberikan pendidikan secara holistic dan integratif, yaitu memadukan pembelajaran umum dan pembelajaran agama. Melalui budaya sekolah yang didukung dengan penerapan sistem boarding school yang mewajibkan siswa untuk tinggal di asrama selama menempuh pendidikan. Tentunya dengan tinggal di asrama pergaulan siswa menjadi lebih terjaga karena dibatasi oleh lingkungan asrama serta pengawasan dan kontrol yang terus berjalan.

Kegiatan-kegiatan maupun program yang dilaksanakan di dalam asrama tersebut tentunya adalah program yang dapat mendukung perkembangan karakter siswa menjadi lebih baik. Seperti program tahfiz al Qur'an, diniyah, shalat tahajud dan yang lainnya. Melalui sistem boarding school yang diterapkan tersebut menjadikan pendidikan karakter berbasis budaya sekolah ini semakin efektif. Selain itu sistem boarding school ini menjadikan peserta didik mendapatkan pendidikan berupa keteladanan, pembiasaan lebih banyak dan intens. Melalui sistem boarding school ini pula proses sosialisasi dan interaksi positif diantara siswa dengan siswa, 
siswa dengan guru akan lebih sering terjalin, sehingga secara tidak langsung akan memberikan pengaruh terhadap sikap maupun perilaku siswa.

Sistem Boarding School di SMP IT GMC ini dalam pengelolaannya, guru selain sebagai pengajar disekolah juga merangkap sebagai pengasuh di asrama dan semua guru mendapatkan jadwal piket menjadi pengasuh secara bergilir setiap minggunya. Hal ini tentunya memberikan efek positif terutama dalam pengawasan dan kontrol oleh guru terhadap siswa. Sistem sekolah setengah hari seperti halnya kebanyakan sekolah umum, tidak memberikan ruang dan waktu yang cukup untuk memantau dan melihat perkembangan siswa, guru hanya bisa memantau perilaku dan sikap siswa hanya ketika berada disekolah, selebihnya siswa tidak mendapatkan pengawasan. Oleh karena itu dengan penerapan sistem boarding school ini, dimana guru diberdayakan juga sebagai pengasuh akan memberikan ruang dan waktu yang lebih banyak untuk memantau perkembangan siswa, sehingga akan memudahkan pula bagi guru untuk melakukan evaluasi jika ditemukan kekurangan maupun kelemahan.

Siswa akan terlatih untuk melaksanakan aktivitas-aktivitas ibadah secara konsisten ketika tinggal di asrama, karena di asrama ini siswa selalu diarahkan dan dibimbing untuk senantiasa disiplin melaksanakan ibadah terutama ibadah wajib seperti shalat fardhu. Tidak hanya itu, diasrama ini juga siswa mendapatkan pelajaran agama Islam lebih banyak, seperti pelajaran akhlak, fiqih dan tajwid, yang tentunya akan mendukung perkembangan karakter siswa.

Berdasarkan fenomena diatas, maka pada tulisan ini akan dibahas tentang Implementasi Pendidikan Karakter Berbasis Budaya Sekolah Melalui Penerapan Sistem Boarding School di SMP IT Generasi Muslim Cendekia Lombok Tengah dengan memfokuskan kajian pada nilai-nilai karakter yang dikembangkan, strategi yang digunakan serta implikasinya terhadap karakter siswa.

\section{METODE PENELITIAN}

Penelitian ini menggunakan pendekatan kualitatif dengan jenis penelitian studi kasus. Data diperoleh dengan menggunakan teknik observasi partisipatif, wawancara secara mendalam dan arsip. Analisis data dilakukan melalui tahapan reduksi data, penyajian data dan penarikan kesimpulan. Keabsahan data dicek dengan meningkatkan ketekunan pengamatan, triangulasi (sumber, teknik dan waktu) dan member check. 


\section{HASIL DAN PEMBAHASAN}

\section{Nilai-nilai Karakter yang Dikembangkan di SMP Islam Terpadu Generasi Muslim Cendekia Melalui Penerapan Sistem Boarding School}

a. Religius

Karakter religius sebagaimana dalam penjabarannya yaitu sikap dan perilaku yang patuh dalam melaksanakan ajaran agama yang dianutnya. Karakter religius merupakan merupakan salah satu karakter dasar yang sangat penting dan merupakan sebuah keharusan untuk ditanamkan sejak dini. Pemahaman akan ajaran agama Islam serta kepatuhan dalam melaksanakan segala bentuk ritual yang diperintahkan seperti halnya shalat, akan berimplikasi pada kebaikan sikap dan perilaku siswa.

Sebagaimana Allah SWT berfirman dalam al Qur'an surat al Ankabut ayat 45 :

"bacalah apa yang telah diwahyukan kepadamu, Yaitu Al kitab (Al Quran) dan dirikanlah shalat. Sesungguhnya shalat itu mencegah dari (perbuatanperbuatan) keji dan mungkar".

M. Quraish Shihab dalam tafsir al Misbah menjelaskan bahwa apabila ahalat dikerjakan secara berkesinambungan dan khusu' sebagaimana Allah dan Nabi tuntunkan serta memenuhi rukun, syarat dan sunnahnya, maka akan mampu menjaga dan mencegah orang yang melakukannya dari pebuatan keji dan mungkar. (M. Quraish Shihab 2002)

Menurut Muhaimin, segala bentuk ucapan, perbuatan maupun pikiran mestinya dibangun dan dilandasi oleh nilai ketuhanan, yaitu dengan memahami dan mengamalkan ajaran agama yang dianutnya secara baik dan benar. Apabila karakter kepada Tuhannya telah terbangun dengan baik, maka segala aspek kehidupan terkait dengan sesamanya pun akan tejalin dengan baik, karena ajaran agama menghendaki hubungan baik tidak hanya dengan Tuhan namun juga sesama makhluk ciptaanNya (Akmad Muhaimin Azzet 2011)

b. Disiplin

Disiplin merupakan salah satu karakter yang perlu dikembangakan disekolah. Banyaknya perilaku menyimpang seperti mencontek saat ujian, tidak memasukkan baju, merokok disekolah, membuang sampah 
sembarangan, merusak fasilitas sekolah dan lainnya, menunjukkan permasalahan yang serius tentang disiplin. Pentingnya disiplin ini adalah dapat mendorong tumbuhnya karakter-karakter baik lainnya seperti tanggung jawab, jujur, peduli dan lainnya. Apabila mengacu pada wawancara dengan kepala sekolah SMP Islam Terpadu GMC menyatakan bahwa apabila disiplin ini dapat dilaksanakan secara maksimal, tentunya segala program atau kegiatan akan dapat berjalan juga dengan maksimal sehingga hasil yang diharapkan juga lebih maksimal (Abdul Majid 2019)

Lickona menyatakan bahwa dengan disiplin diri seseorang akan diarahkan untuk mencari dan melakukan hal yang positif, dengan disiplin diri juga seseorang tidak akan cenderung untuk tidak mengikuti kehendak hati dengan merendahkan dan merusak diri (Thomas Lickona 1992).

c. Hormat dan santun

Banyaknya peristiwa penganiayaan terhadap guru disekolah menunjukkan rasa hormat dan santun terhadap guru perlu untuk diajarkan dan dikembangkan sejak dini. Begitu pula sebaliknya penganiayaan terhadap siswa menunjukkan rendah rasa santun dari seorang guru terhadap siswa. Oleh karena itu dalam rangkan mengembangkan karakter ini dibutuhkan kesadaran dan peran dari siswa dan juga guru.

Sebagaimana yang dilakukan guru dan siswa di SMP Islam Terpadu GMC, rasa hormat dan santun dimulai dari hal yang paling sederhana yaitu panggilan, guru memanggil siswa dengan sebutan yang dapat menumbuhkan rasa kasih sayang seperti "dinda" atau "nak". Hal ini mengjarkan kepada siswa bahwa sebagai juga senantiasa untuk santun dan lemah lembut kepada siswa. Hal yang sebaliknya juga sebagaimana dipraktikkan siswa, ketika dipanggil siswa tidak mengatakan iya akan tetapi "tiang" yang artinya saya dalam bahasa halus.

Wahyudi dan I Made Arsana menyebutkan bahwa seseorang yang berkarakter sopan santun memiliki perilaku sebagai berikut :

1) Hormat kepada yang lebih tua

2) Menggunakan tangan kanan untuk menerima pemberian

3) Bertutur kata yang sopan, lemah lembut dan rendah hati

4) Tidak meludah disembarang tempat

5) Mengucap salam ketika bertemu guru 
6) Apabila orang lain punya pendapat, ia hormati (Wahyudi, Didik dan I Made Arsana. 2014).

Berdasarkan indikator tersebut sebagian besar telah dipraktekkan di SMP Islam Terpadu GMC, meskipun hasilnya belum maksimal namun telah menunjukkan beberapa perubahan kearah yang lebih baik.

d. Peduli sosial

Sebagai makhluk yang senantiasa butuhkan kepada orang lain, maka menanamkan karakter kepedulian pada siswa juga menjadi penting, karena kian hari rasa kepedulian terhadap sesama semakin hari semakin terkikis dan tergantikan dengan budaya egoisme. Oleh karena itu dengan penerapan sistem boarding school ini rasa kepedulian dan kepekaan terhadap sesama dapat lebih dutumbuhkan. Dengan kondisi lingkungan dimana interaksi terjalin secara intens setiap hari diharapkan dapat menumbuhkan secara perlahan rasa kepedulian pada siswa. Kurangnya rasa peduli dan kepekaan siswa pada masa sekarang ini lebih diakibatkan oleh kurangnya sosialisasi dan interaksi disebabkan kecanduan oleh teknologi seperti smartphone atau gadget yang pada gilirannya menimbulkan sikap individualistik, dimana orang dapat duduk berdampingan namun tidak ada interaksi yang terjalin.

Pentingnya karakter ini untuk dikembangkan adalah untuk mendidik siswa agar dapat menjalin hubungan baik dengan selain dirinya, karena bagaimanapun siswa juga merupakan makhluk sosial yang selalu terhubung dengan orang lain, baik dilingkungan keluarga, masyarakat maupun sekolah(Syaiful Bahri, D. 1997). Disamping itu juga untuk mendukung keberhasilan dan prestasi belajar, karena keberhasilan dan prestasi belajar tidak hanya dipengaruhi olek faktor kecerdasan semata namun juga dipengaruhi oleh hubungan atau relasi sosialnya dengan guru(Slameto 1995).

e. Peduli lingkungan

Menjaga serta melestarikan lingkungan merupakan tanggung jawab setiap orang, namun tidak semua orang menyadari melaksanakannya. Hal itu pula yang menjadi fakto bagi SMP IT GMC Lombok Tengah untuk mengembangkan karakter peduli lingkungan, yaitu dengan melaksanakan program pembersihan yang dimulai dari lingkungan sekolah maupun diluar lingkungan sekolah. Siswa diajarkan untuk senantiasa menjaga, melestarikan lingkungan alam karena manusia dan alam sama-sama saling 
ketergantungan. Kepedulian terhadap lingkungan hendaknya dimulai dari lingkungan terdekat kita seperti rumah, sekolah tempat dimana kita beraktivitas sehari hari. Sebagaimana diungkapkan oleh Hindarsih bahwa kepedulian terhadap lingkungan ditunjukkan dengan menjaga dan memperhatikan lingkungan sekitar (Kurniawan, Yudha dan Tri Puji Hindarsih 2013).

Menurut Hamzah bahwa pendidikan lingkungan adalah sebuah kebutuhan yang tak terelakkan bila kita ingin mewujudkan masyarakat madani seperti yang dicita-citakan (Syukri Hamzah 2013). Lebih lanjut ia mengatakan bahwa untuk bisa memiliki karakter peduli lingkungan seseorang hendaknya belajar karena karakter ini bukan suatu bawaan akan tetapi didapatkan melalui suatu proses pendidikan.

Berdasarkan paparan tersebut maka mengembangkan karakter peduli lingkungan di sekolah merupakan hal yang sangat dibutuhkan, dengan pembelajaran, pembuatan program serta pembiasaan yang dilakukan secara konsisten akan dapat menumbuhkan rasa peduli terhadap lingkungan yang tentunya muncul dan didasari oleh kesadaran siswa. Akan semakin efektif pula pendidikan karakter peduli lingkungan ini karena didukung dengan penerapan sistem boarding school yang memberikan pembiasaan dan program secara terprogram sehingga siswa secara dapat belajar secara konsisten.

\section{Strategi Implementasi Pendidikan Karakter Berbasis Budaya Sekolah} Melalui Penerapan Sistem Boarding School di SMP Islam Terpadu Generasi Muslim Cendekia

Pendidikan karakter pada lembaga pendidikan formal seperti sekolah adalah merupakan suatu keharusan. Melalui pendidikan karakter diharapkan generasi bangsa yang akan datang tidak hanya cerdas namun juga memiliki budi yang luhur. Melalui penerapan sistem boarding school, SMP Islam Terpadu Generasi Muslim Cendekia berupaya untuk memberikan pendidikan karakter dengan lebih maksimal untuk membentuk siswa yang tidak hanya cerdas namun juga siswa yang memiliki karakter dan budi pekerti yang luhur.

Menurut Lickona bahwa karakter yang baik itu meliputi tiga komponen yaitu : pengetahuan tentang moral (moral knowing), perasaan moral (moral 
feeling), perbuatan moral (moral action) (Thomas Lickona 1992). Berdasarkan teori tersebut, maka pendidikan karakter berbasis budaya sekolah melalui penerapan sistem boarding school di SMP Islam Terpadu Generasi Muslim Cendekia adalah dalam rangka mengembangkan tiga komponen tersebut yang dilakukan dengan beberapa strategi sebagai berikut :

a. Internalisasi nilai-nilai positif oleh semua warga sekolah

Mengembangkan karakter siswa menjadi lebih baik tentunya harus diawali terlebih dahulu dengan pengetahuan dengan memahami seperti apa karakter yang baik itu. Lickona dalam bukunya menyebutkan diantara 3 (tiga) komponen karakter salah satunya adalah moral Knowing (pengetahuan moral) (Thomas Lickona 1992). Moral knowing merupakan tahapan pertama dari tiga tahap yang harus dilalui dalam pendidikan karakter. Pada tahap pertama ini berorientasi pada penguasaan terhadap nilai-nilai, yang meliputi :

1) Mampu menilai akhlak yang baik dan buruk, mana yang perlu dilakukan dan tidak boleh atau terlang untuk dilakukan.

2) Mampu menguasai dan memahaminya secara logis dan rasional, (bukan hanya sekedar dogmatis dan doktriner) mengapa nilai- akhlak mulia itu perlu dimiliki dan dipraktekkan didalam kehidupan dan mengapa nilai akhlak buruk itu perlu dihindari.

3) Dapat mengenal tokoh teladan akhlak (karakter) yang dipelajari melalui berbagai kajian termasuk tokoh teladan utama itu adalah Nabi Muhammad SAW sebagai suri tauladan terbaik bagi manusia (Heri Gunawan 2012)

Oleh karena itu mempelajari tentang karakter yang baik itu menjadi hal yang mesti dilakukan. Melalui sistem boarding school ini yang mewajibkan siswa untuk tinggal didalamnya, memberikan kesempatan bagi mereka untuk mempelajari berbagai hal termasuk tentang karakter-karakter yang baik. Beberapa mata pelajaran yang menjadi fokus untuk dipelajari siswa di asrama adalah terkait dengan pelajaran agama Islam.

Apabila berbicara tentang karakter yang berhubungan dengan kualitas sikap dan perilaku seseorang, maka sungguh tepat apabila yang dipelajari adalah agama Islam. Karena ajaran Islam itu sendiri didalamnya mengandung banyak sekali akan nilai-nilai karakter yang bisa dipelajari. Apabila diperhatikan dan dicermati, bagaimana Islam mengajarkan untuk senantiasa patuh kepada Allah dan Rasulnya, mengajarkan untuk berbakti kepada kedua 
orang tua, bagaimana Islam mengajarkan untuk menghormati tetangga serta memuliakan tamu sekalipun bukan orang Muslim.

Islam mengajarkan untuk senantiasa jujur dan bertutur kata yang baik, kepada orang yang lebih tua hendaknya dihormati dan kepada yang lebih kecil hendaknya disayangi. Apabila memiliki kelebihan rizki hendaknya mengeluarkan zakatnya, bersedekah meskipun hanya dengan senyuman. Semua itu menunjukkan bahwa dengan siswa mempelajari ajaran agama Islam sesungguhnya telah mempelajari bagaimana karakter-karakter yang baik.

b. Keteladanan

Keteladanan merupakan hal penting didalam pendidikan karakter. Guru sebagai figur pendidik hendaknya mampu menjadi teladan yang baik bagi siswanya, tidak hanya mampu mengajarkan ataupun mengarahkan melainkan mampu menjadi contoh yang bisa ditiru secara nyata oleh siswa. Aminullah sebagaimana dikutip Hendriana mengungkapkan bahwa guru memiliki peran yang strategis bagi kemajuan dan peradaban bangsa, karena guru tidak hanya hidup untuk dirinya namun ia juga merupakan cermin indah bagi ratusan bahkan ribuan anak didiknya (Hendriana dan Jacobus 2017)

Guru sebagai seorang figur penting dalam pendidikan harus mampu menjadi apa yang dikatakan oleh KI Hadjar Dewantara "Ing Ngarsa SungTuladha, Ing Madya Mangun Karsa, Tut Wuri Handayani" yaitu menjadi teladan ketika berada didepan, memberi semangat ketika berada ditengah dan menjadi pendorong ketika berada dibelakang (Zuhriah 2008). Tentunya hal ini bukan perkara yang mudah, dibutuhkan usaha dan ketekunan serta kesabaran, karena untuk menanamkan karakter pada anak tidak semudah membalikkan telapak tangan.

Tahapan kedua dari pendidikan karakter yaitu moral feeling (perasaan moral) dapat dilakukan melalui keteladanan ini. Sebagai guru akan lebih efektif apabila ingin membuat siswa mau melakukan sesuatu yang baik apabila diawali oleh guru tersebut. Karena karakter sesungguhnya menuntut seseorang untuk melakukan sesuatu karena perasaan cinta (loving the good), bukan karena ada paksaan ataupun hukuman, oleh karena adanya perasaan cinta itu sehingga timbul keinginan untuk melakukan kebaikan (desiring the good) (Heri Gunawan 2012). Sehingga pada tahapan yang kedua ini yang 
menjadi tujuannya adalah aspek emosional. Pada tahapan yang kedua ini yang dilakukan adalah untuk menumbuhkan sisi emosional yang meliputi : hati nurani, harga diri, empati, mencintai hal yang baik, kendali diri dan kerendahan hati (Thomas Lickona 1992).

Keteladanan tidak hanya dilakukan melalui percontohan langsung oleh guru, namun dapat pula dilakukan melalui kisah-kisah teladan para tokoh. Teladan utama tentunya adalah Nabi SAW. Sebagaimana Allah SWT. berfirman didalam al Qur'an surat al Ahzab ayat 21 :

"Sesungguhnya telah ada pada (diri) Rasulullah itu suri teladan yang baik bagimu (yaitu) bagi orang yang mengharap (rahmat) Allah dan (kedatangan) hari kiamat dan Dia banyak menyebut Allah."

M. Quraish Shihab dalam tafsir al Misbah menjelakan tentang firman Allah ayat 21 "Kalian benar-benar mendapatkan teladan yang baik pada pribadi Nabi Muhammad. Teladan bagi orang-orang yang mengharap kasih sayang Allah dan kesenangan hidup di akhirat. Teladan bagi orang-orang yang banyak berzikir mengingat Allah di setiap kesempatan, kala susah maupun senang (M. Quraish Shihab 2002).

Teladan yang ada pada Nabi SAW tidak hanya teladan untuk mencapai kebahagiaan didunia, akan tetapi lebih jauh dari itu pada diri Nabi Muhammad terdapat teladan untuk menggapai kasih sayang Allah dan kebahagiaan akhirat. Oleh karena sudah semestinya para guru juga menginspirasi siswa dengan kisah teladan Nabi Muhammad SAW.

c. Pembiasaan

Pendidikan karakter melalui sistem boarding school dicapai juga melalui strategi pembiasaan-pembiasaan. Ibnu Sina sebagaimana dikutip Mansur menyatakan bahwa pembiasaan merupakan metode pengajaran yang dirasa efektif (Mansur 2016. Mulyasa mengungkapkan bahwa pembiasaan merupakan sesuatu yang dilakukan secara rutin dan terus menerus agar menjadi kebiasaan(Mulyasa 2012).

Pendidikan karakter tidak cukup hanya melalui pengajaran dan keteladanan, melainkan juga harus didukung pula dengan pembiasaan yang senantiasa dipraktekkan secara terus menerus dan konsisten sehingga menjadi kebiasaan dan tertanam sebagai karakter yang melekat pada siswa. Pembiasaan merupakan langkah dalam mencapai apa yang disebut oleh 
Lickona sebagai perbuatan atau tindakan moral (moral action) yang merupakan tahapan terakhir dari tiga komponen karakter yang baik. Moral action ini adalah wujud dari tahapan pendidikan karakter yang bisa diamati dan dapat dijadikan tolak ukur keberhasilan. Oleh karena itu tiga aspek karakter yaitu (competence) kompetensi, (will) keinginan dan (habit) kebiasaan adalah satu kesatuan yang dapat membantu memahami alasan seseorang untuk berbuat kebaikan(Heri Gunawan 2012).

Mengetahui dan mencintai hal yang baik bukanlah jaminan atau garansi seseorang akan berbuat baik, maka diperlukan pembiasaan untuk melakukan hal yang baik. Oleh karena itu diperlukan suatu pengkondisian lingkungan yang dapat mendukung pembiasaan tersebut sehingga dapat berjalan lebih efektif. Sistem boarding school yang diterapkan di SMP Islam Terpadu ini menyediakan sebuah lingkungan yang dapat mendukung pendidikan karakter melalui pembiasaan. Kondisi lingkungan yang terjaga dari pengaruh negatif yang datang dari luar, fasilitas yang mendukung dan pengawasan yang selalu dilakukan diharapkan mampu membentuk dan memperkuat karakter siswa.

Keutamaan hidup sebagaimana diungkapkan Aristoteles, diperoleh melalui kebiasaan melakukan hal yang baik, dengan kebiasaan itu maka akan tercipta struktur hidup yang menjadikan seseorang mudah untuk berbuat dan bertindak. Sehingga seseorang tidak harus selalu berfikir atau bernalar ketika hendak melalukan suatu perbuatan (Saptono 2011).

d. Penegakan disiplin

Sebagai lembaga pendidikan formal, penting sekali untuk menegakkan kedisiplinan, sebagai langkah untuk menciptakan keamanan dan ketertiban di lingkungan sekolah maupun asrama, juga sebagai upaya untuk membentuk karakter disiplin siswa. Menurut Curvin dan Mendler bahwa perilaku tidak disiplin seringkali terjadi karena tidak adanya pembatasan yang jelas (Curvin \& Mindler 1999). Melalui pembuatan aturan dan tata tertib sekolah, pembatasan akan menjadi jelas, serta didukung dengan sosialisasi kepada orang tua siswa agar aturan dan tata tertib sekolah dapat berjalan dengan baik. Sosialisasi ini menjadi perlu untuk menciptakan kesepahaman guru dan orang tua siswa, sehingga orang tua siswa ikut mendukung penegakkan aturan dan tata tertib di sekolah.

Kedisiplinan akan terwujud menurut Devine apabila kontrol ruang dan 
waktu dijadikan sebagai alat untuk memantau aktivitas siswa (Fadillah Annisa 2019). Sebagaimana telah dipaparkan diawal bahwa SMP Islam Terpadu GMC menerapkan sistem boarding school, sehingga untuk kontrol ruang dan waktu menjadi relatif lebih mudah. Namun diperlukan juga peran orang tua untuk memberikan kontrol ketika siswa berada dirumah.

Strategi penguatan pendidikan karakter melalui penerapan sistem boarding school yang digunakan di SMP Islam Terpadu GMC ini, mempunyai keterkaitan dengan strategi pembentukan karakter sebagaimana yang disampaikan oleh Furqon Hidayatullah yang diantaranya adalah melalui : 1) keteladanan, 2) penanaman/penegakan disiplin, 3) pembiasaan, 4) menciptakan suasana yang kondusif dan 5) integrasi dan internalisasi(Furqin Hidayatullah 2010).

3. Implikasi Pendidikan Karakter Berbasis Budaya Sekolah Melalui Penerapan Sistem Boarding School di SMP IT GMC Terhadap Karakter Siswa

Implikasi merupakan sesuatu yang menjadi tolak ukur dari pelaksanaan pendidikan karakter khususnya melalui penerapan sistem boarding school di SMP Islam Terpadu GMC. Semakin besar implikasi yang dihasilkan menunjukkan pelaksanan pendidikan karakter semakin baik begitu pula sebaliknya semakin kecil implikasi yang dihasilkan menunjukkan pelaksanan pendidikan karakter masih banyak kekurangan dan masih perlu perbaikan.

Bedasarkan paparan data sebelumnya bahwa pendidikan karakter berbasis budaya sekolah melalui penerapan sistem boarding school berimplikasi kuat terhadap karakter siswa. Melalui pembiasaan, keteladanan dan pengawasan yang dilakukan secara intens, dengan sendirinya karakter siswa semakin baik. Meskipun belum 100\% akan tetapi perubahan pada anak dapat terlihat dan rasakan. Merujuk pada tujuan pendidikan karakter sebagaimana diungkapkan oleh Dharma Kesuma yaitu :

a. Menguatkan dan mengembangkan nilai-nilai kehidupan yang dianggap penting dan perlu sehingga menjadi kepribadian/kepemilikan peserta didik yang khas sebagaimana nilai-nilai yang dikembangkan;

b. Menyesuaikan perilaku peserta didik dengan nilai-nilai yang dikembangkan oleh sekolah; 
c. Membanguan koneksi yang harmoni dengan keluarga dan masyarakat dalam memerankan tanggung jawab pendidikan karakter secara bersama (Dharma Kesuma 2012)

Apabila dilihat dari implikasi penguatan pendidikan karakter melalui penerapan sistem boarding school di SMP Islam Terpadu, maka dapat dikatakan sekolah telah mampu menguatkan dan mengembangkan nilai-nilai kehidupan yang dianggap penting dan perlu seperti nilai-nilai religius, kedisiplinan, rasa kepedulian baik itu terhadap sosial dan lingkungannya.

Sekolah mampu memperbaiki perilaku siswa yang tidak bersesuaian dengan nilai-nilai yang dikembangkan oleh sekolah. Sebagaimana visi sekolah yaitu mencetak generasi Qur'ani yang scientific, berakhlak mulia, berbudi pekerti dan berdaya saing, yang selanjutnya dalam misinya disebutkan Islam dijadikan sebagai identitas diri dan gaya hidup. Oleh karena itu, setiap sikap dan perilaku siswa di SMP Islam Terpadu GMC disesuaikan dengan nilai-nilai Islam.

Serta sekolah mampu membangun koneksi dengan keluarga dan masyarakat dalam memerankan tanggung jawab pendidikan karakter secara bersama. Melalui mejelis ta'lim yang diadakan setiap sekali seminggu yang juga melibatkan orang tua siswa dan masyarakat khususnya masyarakat sekitar menjadikan sosialisasi serta bangunan koneksi menjadi lebih kuat.

Agus Zainal Fitri dalam bukunya juga mengungkapkan bahwa pendidikan karakter bertujuan untuk membentuk dan membangun pola pikir, sikap dan perilaku peserta didik agar menjadi pribadi yang positif, berakhlakul karimah, berjiwa luhur dan bertanggung jawab (Agus Zainal Fitri 2012). Untuk mewujudkan tujuan tersebut tentunya diperlukan situasi lingkungan yang kondusif yang mampu mendukung proses tersebut. Sistem boarding school yang di terapkan di SMP Islam Terpadu GMC ini telah mampu menyediakan lingkungan yang kondusif dan mampu mendukung terbentuknya proses tersebut. Terbukti dari temuan sebagaimana telah dipaparkan pada bab sebelumnya, dimana terjadi beberapa perubahan positif pada siswa, seperti perubahan terhadap sikap spiritual, sikap sosial, kedisiplinan serta perilakusiswa kearah yang lebih baik.

\section{SIMPULAN}


Nilai-nilai karakter yang dikembangkan di SMP Islam Terpadu GMC melalui penerapan sistem boarding school yaitu : 1) karakter religius, 2) disiplin, 3) hormat dan santun, 4) peduli sosial, 5) peduli lingkungan. Strategi implementasi pendidikan karakter berbasis budaya sekolah melalui penerapan sistem boarding school meliputi : 1) internalisasi nilai-nilai positif oleh semua warga sekolah; 2) keteladanan; 3) pembiasaan; 4) penegakkan disiplin. Implikasi pendidikan karakter berbasis budaya sekolah melalui penerapan sistem boarding school terhadap karakter siswa dapat dilihat dari 4 aspek yaitu : 1) implikasi terhadap sikap spiritual, 2) implikasi terhadap kedisiplinan, 3) implikasi terhadap sikap sosial dan 4) implikasi terhadap akhlak dan perilaku.

\section{DAFTAR PUSTAKA}

Annisa, Fadillah. 2019. "Penanaman Nilai-Nilai Pendidikan Karakter Disiplin Pada Siswa Sekolah Dasar." Jurnal Perspektif Pendidikan Dan Keguruan 10 (1): 69-74. https://doi.org/10.25299/perspektif.2019.vol10(1).3102.

Curvin, .R. L., \& Mindler, A. N. Discipline With Dignity. (USA: Association For Supervision And Curriculum Development, 1999), 8

Daulay, Haidar Putra, Pendidikan Islam dalam Pendidikan Nasional di Indonesia (Jakarta : Kencana,2012)

Dharma Kesuma, Pendidikan Karakter Kajian Teori dan Praktik di Sekolah, (Bandung : Remaja Rosdakarya, 2012).

Furqon Hidayatullah. Pendidikan Karakter Membangun Peradaban Bangsa. (Surakarta : Yuma Pustaka, 2010), 39

Hamzah, Syukri. Pendidikan Lingkungan: Sekelumit Wawasan Pengantar. (Bandung: Refika Aditama, 2013), 37

Hasan, Yetri, dan Rijal Firdaos. 2017. "Penguatan Pendidikan Karakter Berbasis Masyarakat Pada Sekolah Menengah Pertama Negeri (SMPN) Di Kabupaten Tulang Bawang Provinsi Lampung." Al-Tadzkiyyah: Jurnal Pendidikan Islam 8 (2): 267-79. https://doi.org/10.24042/atjpi.v8i2.2131.

Hendriana, Evinna Cinda, dan Arnold Jacobus. 2017. "Implementasi Pendidikan Karakter Di Sekolah Melalui Keteladanan Dan Pembiasaan." JPDI (Jurnal Pendidikan Dasar Indonesia) 1 (2): 25-29. https://doi.org/10.26737/jpdi.v1i2.262.

Heri gunawan, Pendidikan Karakter: Konsep dan Implementasi, (Bandung : Alfabeta, 2012). 28

Khamalah, Nur. 2017. "Penguatan Pendidikan Karakter Di Madrasah." Jurnal Kependidikan 5 (2): 200-215. https://doi.org/10.24090/jk.v5i2.2109.

Mansur, A. Pendidikan Karakter Berbasis Wahyu. (Jakarta: Gaung Persada, 2016), 93. 
M. Quraish Shihab, Tafsïr al-Mișbah Volume 10, (Jakarta: Lentera Hati, 2002), 506 Mulkhan, Abdul Munir. 2016. "Pendidikan Islam dalam GBHN dan Realitas Kebangsaan." UNISIA 0 (33): 69-86. https://doi.org/10.20885/unisia.v0i33.5840.

Munjiatun, Munjiatun. 2018. "Penguatan Pendidikan Karakter: Antara Paradigma Dan $\begin{array}{lllll}\text { Pendekatan." Jurnal Kependidikan } 6 & \text { (2): 334-49. }\end{array}$ https://doi.org/10.24090/jk.v6i2.1924.

Murniyetti, Murniyetti, Engkizar Engkizar, dan Fuady Anwar. 2016. "Pola Pelaksanaan Pendidikan Karakter Terhadap Siswa Sekolah Dasar." Jurnal Pendidikan Karakter 6 (2). https://doi.org/10.21831/jpk.v6i2.12045.

Mulyasa. Manajemen Pendidikan Karakter. (Jakarta: Bumi Aksara, 2012), 166

Purnama, Herwulan Irine, Marzuki Marzuki, dan Sri Utami. 2018. "Penguatan Pendidikan Karakter Berbasis Budaya Sekolah Melalui Program Literasi Dasar Di Sekolah Dasar Negeri Pontianak." Jurnal Pendidikan Dan Pembelajaran 7 (3). http://jurnal.untan.ac.id/index.php/jpdpb/article/view/24722.

Saptono, Dimensi-Dimensi Pendidikan Karakter (Wawasan, Strategi, dan langkah Praktis), (Jakarta: Erlangga, 2011), 58

Slameto. Belajar dan Faktor-Faktor yang Mempengaruhi. (Jakarta: Bina Aksara, 1995), 54.

Syaiful Bahri, D. dan Asuran Zain. Strategi Belajar Mengajar. (Jakarta: Rineka Cipta,1997),203.

Syamsuar, Syamsuar, dan Reflianto Reflianto. 2019. "Pendidikan Dan Tantangan

Pembelajaran Berbasis Teknologi Informasi Di Era Revolusi Industri 4.0." E-Tech: Jurnal IImiah Teknologi Pendidikan 6 (2). https://doi.org/10.24036/et.v2i2.101343.

Thomas Lickona, Educating For Character: How Our School Can Teach Respect and Responsibility, (New York:Bantam Books, 1992), 12-22.

Wahyudi, Didik dan I Made Arsana. 2014. "Peran Keluarga Dalam Membina Sopan Santun Anak Di Desa Galis Kecamatan Galis Kabupaten Pamekasan". Jurnal Kajian Moral dan Kewarganegaraan. Nomor 2 Vol 1 Tahun 2014, 290 -304.

Wawancara dengan Abdul Majid, selaku kepala sekolah, pada 1 November 2019

Zuhriah, Pendidikan Moral dan Budi Pekerti dalam Perspektif Perubahan, (Jakarta:Bumi Aksara, 2008), Cet II, H. 131.

Zuriah, Nurul, Pendidikan Moral dan Budi Pekerti dalam Perspektif Perubahan. (Jakarta: Bumi Aksara, 2008)

https://siar.com/era-revolusi-industri-4-0-harus-diikuti-penguatan-pendidikankarakter/

https://memontum.com/63906-perkuat-pendidikan-karakter-di-era-revolusi-industri-4$\underline{0}$ 